\title{
An Overview of the First Organic Shrimp Model in the Mekong Delta of Vietnam
}

\author{
Tho Nguyen* and Tu Tran Thi Kim \\ Ho Chi Minh City Institute of Resources Geography, Vietnam Academy of Science and Technology (VAST), 01 Mac Dinh Chi Str., Dist., 1, Ho Chi Minh \\ City, Vietnam
}

${ }^{\star}$ Corresponding author: Tho Nguyen, Ho Chi Minh City Institute of Resources Geography, Vietnam Academy of Science and Technology (VAST), 01 Mac Dinh Chi Str Dist, Ho Chi Minh City, Vietnam; Email: ntho@hcmig.vast.vn

Received: November 24, 2021; Accepted: November 30, 2021; Published: November 30, 2021

\begin{abstract}
Organic agriculture has become a global trend when the demand for cleaner products is on the increase worldwide. This paper reviews several important aspects and assesses the possibility of further expansion of the first internationally certified organic shrimp model in the coastal part of the Mekong delta of Vietnam. The model seems appropriate in physical terms (quality of water, sediment, and soils; mangrove growth) and shrimp yields. However, managerial challenges (e.g. assessment methods for certification, mechanism of payment, benefit sharing, social, and environmental benefits) still exist and make its efficacy questionable. Accordingly, the model has not been very interesting to the coastal communities. Although strongly favored by the natural conditions and supported by international organizations and the government, the model would be expanded further in the coastal part of the Mekong delta of Vietnam if these challenges are mitigated.
\end{abstract}

\section{Organic Shrimp Models for Cleaner Products}

Organic agriculture has developed rapidly and become a trend worldwide recently in the context of increasing demands for cleaner products $[1,2]$. In aquaculture sector, organic shrimp models are introduced in which shrimps and mangroves are raised in the same farms in a near-natural environment [3-5]. These models have been developed in the coastal areas of many countries in the tropics, such as Thailand, Bangladesh, Indonesia, India, Madagascar, and Vietnam [3,6-8]. In general, shrimps are raised in polyculture systems without using antibiotics and chemicals, and with special emphasis on the protection of mangrove forests and mangrove ecosystems [9]. Shrimps harvested from the models are examined and certified as 'organic shrimp' by several organizations such as the Ecocert (France), IMO - Institute of Market Ecology (Switzerland), National Programme for Organic Production (India), and Japanese Agricultural Organic Standard (Japan). With the rising health and environmental awareness of global consumers, these models are expected to grow faster in the near future $[10,11]$.

Naturland is one of the world's leading international associations for organic agriculture $[9,12]$. The principles of Naturland for organic aquaculture are composed of:

1. Careful selection of sites for aquaculture farms.

2. Protection of adjacent ecosystems

3. Active avoidance of conflicts with other users of the aquatic resources (e.g. fishermen)

4. Prohibition of chemicals (e.g. as anti-fouling agents in net pens)
5. Natural remedies and treatments in the case of disease

6. Feedstuff from organic agriculture

7. Fishmeal and fish oil in feed derived from by-products of fish processed for human consumption (no dedicated feed fishery)

8. Prohibition of genetically modified organisms (GMOs), either in feedstuff or in the stock itself

9. Processing according to organic standards $[9,13]$.

The First Organic Shrimp Model in the Mekong Delta of Vietnam

\section{Introduction of the Model}

The Mekong delta of Vietnam has a long coastline along which mangrove forests reside. In this coastal part, shrimp aquaculture has a long history and plays a key role in the coastal economy [13-15]. On the basis of the mixed shrimp-mangrove systems developed from the 1980s, the first organic shrimp model was introduced to Tam Giang commune, Nam Can district, Camau province, Mekong delta of Vietnam in 1999 and certified in 2001 by Naturland [9,16] (Figure 1). By 2010, around 1,000 integrated shrimp-mangrove farms had been certified by the German organic certification scheme Naturland and audited by the certification body IMO $[17,18]$ in this area. The shift from non-organic to organic farms in this province does not require large changes in farm's infrastructure or management because these characteristics have been similar between the two [19].

In this model, most farms range from $4-5$ ha in size. Mangroves in the farms are pure stands of replanted Rhizophora (Rhizophora 


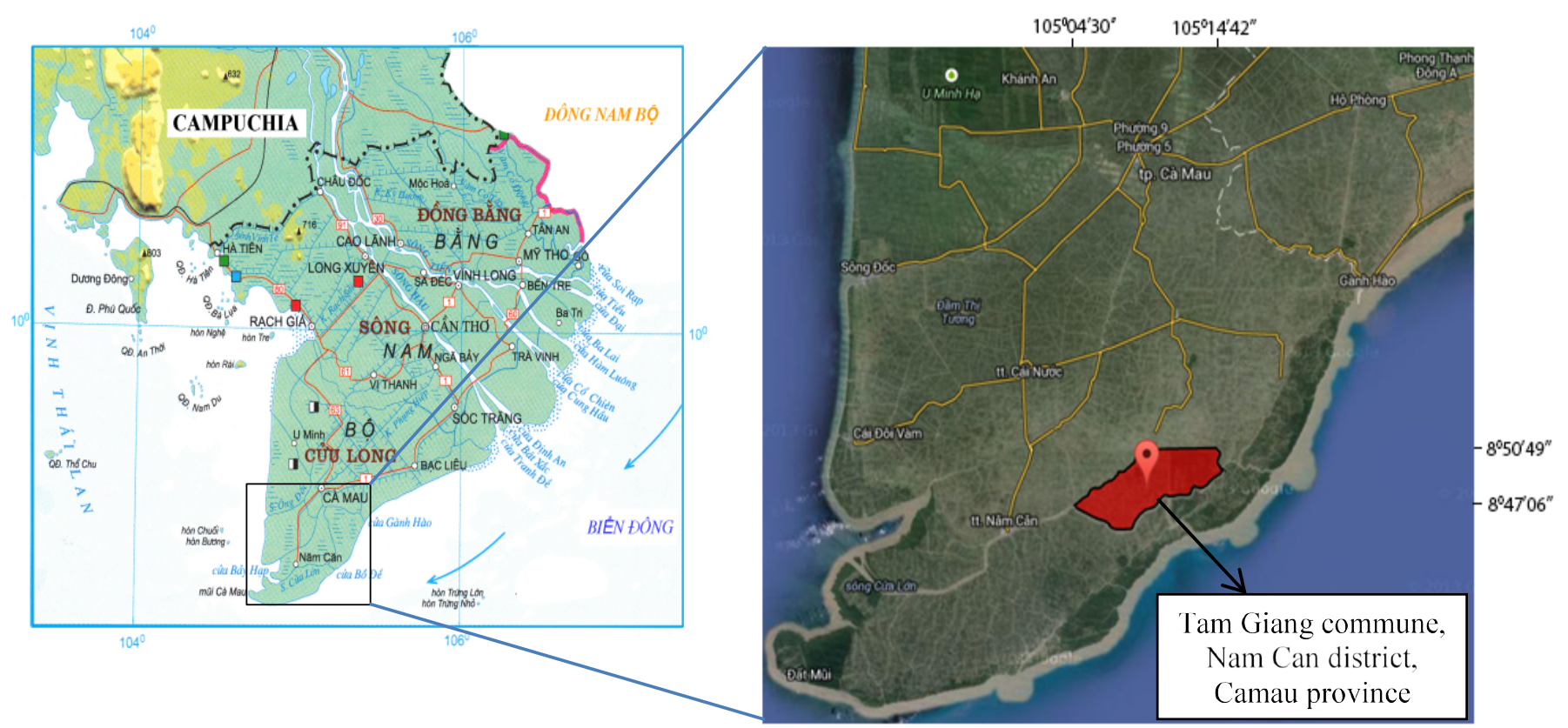

Figure 1: Mekong delta of Vietnam (left) and location of the first Naturland's organic farm (right).

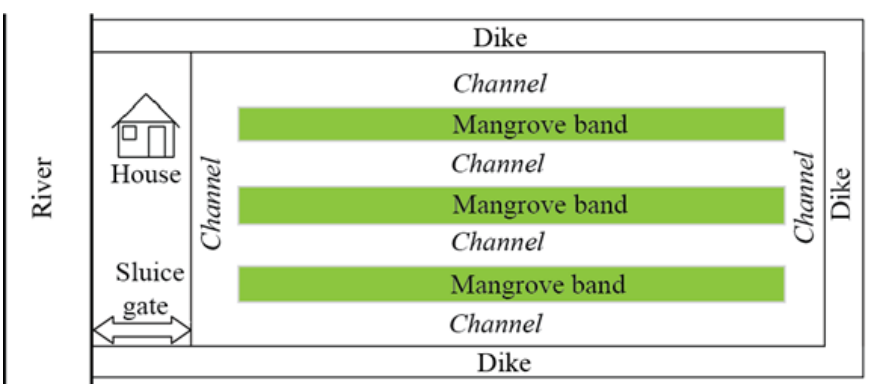

Figure 2: Layout of the first organic shrimp model in Tam Giang commune, Nam Can district.

apiculata Blume) with an averaged density of 10,000 trees.ha $^{-1}$, and the forest ratio must be of at least $50 \%$ of the whole pond area [16]. Black tiger shrimp (Penaeus monodon Fabricius, 1798) are cultured at low densities in mixed pattern with the mangroves (Figure 2), often with marine crab (Scylla serrata Forskal, 1775), blood cockle (Anadara granosa Linnaeus, 1758), and wild shrimps [3,4]. A typical organic shrimp model and its sluice gate are shown in Figure 3.

Black tiger shrimps harvested from the model are expected to meet the current international organic standards (e.g. EU organic regulations, Naturland standard, or Bio Suisse standard) and have been accepted in Swiss and EU markets $[4,16]$. After exporting to EU, the value of these shrimps will increase $20 \%$ from which the shrimp farmers, traders, and processing factories receive respectively $15 \%$, $2 \%$, and $3 \%[20]$. Wild shrimps from the model are sold in the local market [4].

\section{Cropping Calendar, Stocking Density, and Farm Management}

A new production cycle starts in September and ends in July the following year. Farm water is taken from the rivers at high tides with the use of a net $(1 \mathrm{~cm} \times 1 \mathrm{~cm})$ to prevent undesired objects and aggressive fish. The 15-day postlarvae of black tiger shrimp are screened for subclinical levels of pathogens [21] before stocking. The stocking density at the start of the production cycle was from 3-5 postlarvae. $\mathrm{m}^{-2}$ and about $50 \%$ more postlarvae were supplemented in the following months until February-March. Wild shrimps (Penaeus indicus H. Milne Edwards, 1837, Penaeus merguiensis de Man, 1888 [in de Man, 1887-1888], Metapenaeus ensis (De Haan, 1844 [in De Haan, 1833-1850]) and Metapenaeus lysianassa (de Man, 1888 [in de Man, 1887-1888])), estimated of less than 1 postlarvae. $\mathrm{m}^{-3}$ of water in 1996 [15] are also introduced to the farms during water intake. Farmers release marine crabs (Scylla serrata Forskal, 1775) to the farms (0.10.2 individual. $\left.\mathrm{m}^{-2}\right)$ after every 3 months. There is no regular water exchange, no chemical use, and shrimps rely completely on natural food. Four to five months after stocking, farmers harvest market-sized shrimps by draining out part of the farm water twice a month (3-4 consecutive days each at the end/start and the middle of the lunar months). As a result of continuous stocking and partial-harvesting method, shrimps of different ages and sizes are present in the farms at a certain point of time during the production cycle. In August, accumulated sediment in the channel is dredged and deposited on the dikes, and quicklime $(\mathrm{CaO})$ is usually used to disinfect the farm bottom after sediment removal $[4,16]$.

\section{Water Depth and Water Characteristics}

The averaged water depth is $68.8 \pm 3.4 \mathrm{~cm}$ [22]. Pond water is alkaline (pH $7.59 \pm 0.07)$ and highly buffered [4,11], similar to other shrimpmangrove systems in the Mekong delta $[23,24]$. The $\mathrm{pH}$ is high in the middle of the dry season $(7.68 \pm 0.07)$ but drops at the start of the wet season $(7.40 \pm 0.06)$ before stabilizes in the transition between the wet and the dry season $(7.70 \pm 0.18)$. In contrast, total iron is lowest in the middle of the dry season $(0.41 \mathrm{mg} / \mathrm{l})$ but increases sharply at the start of the wet season $(1.06 \mathrm{mg} / \mathrm{l})[11,22]$. The $\mathrm{pH}$ drop at the start of the wet season was due to the reception of acidic components washed down from the dikes, a phenomenon commonly observed in aquaculture 


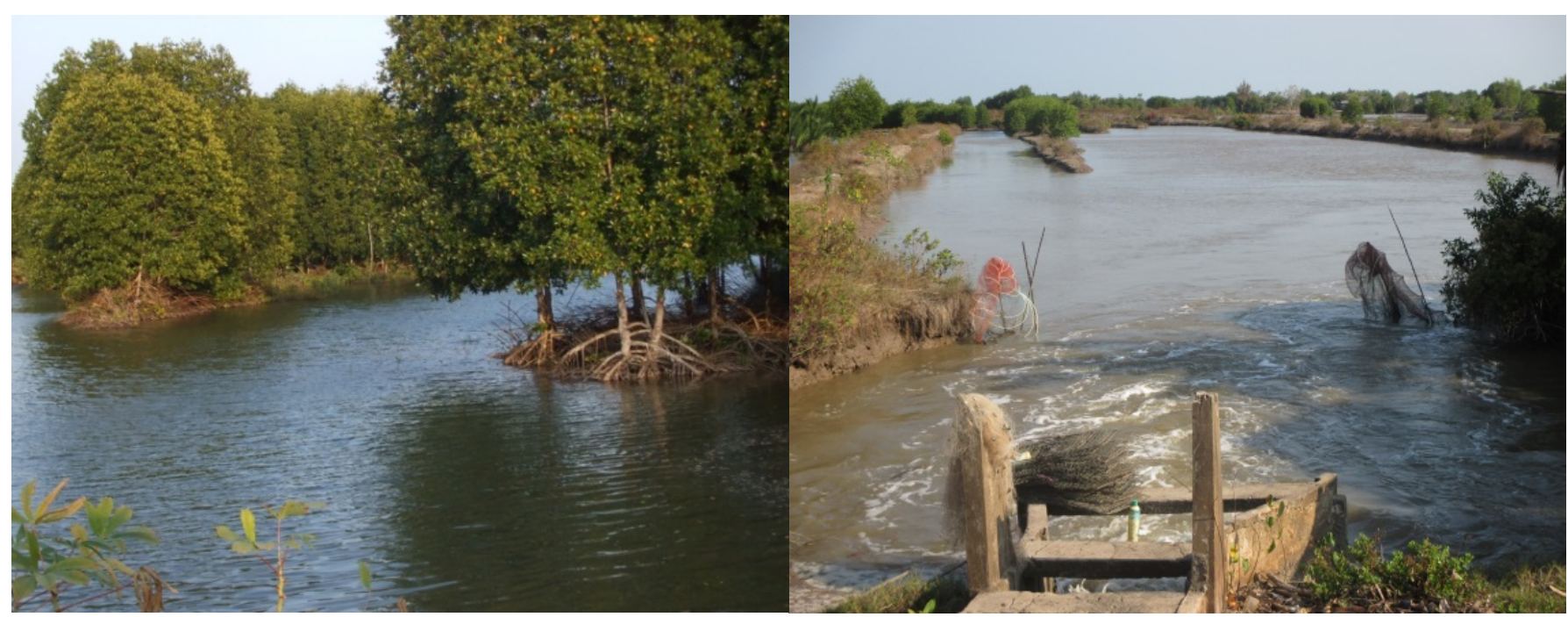

Figure 3: A typical organic shrimp model (left) and its sluice gate (right).

ponds on acid sulfate soils in the Mekong delta [25-27]. Although seasonal changes are observed, $\mathrm{pH}$ of farm water is still within the limits (7-9) for shrimp growth [28]. Because the seasonal $\mathrm{pH}$ drop is not serious, effects of toxic components (e.g. $\mathrm{Al}, \mathrm{Fe}, \mathrm{Mn}$ ) on aquaculture species would still be low in the model $[4,11]$.

\section{Characteristics of Channel Sediment}

Silt $(0.063-0.002 \mathrm{~mm})$ and clay $(<0.002 \mathrm{~mm})$ are dominant, suggesting that suspended matter from intake water is one of the main sources of the sediment. The annual sediment removal does not significantly influence the particle size distribution, revealing that this practice removes only part of the accumulated sediment during the production cycle $[4,29]$. As shown from Table 1 [29], the sediment is reduced with a high $\mathrm{Fe}^{2+} / \mathrm{Fe}^{3+}$ ratio and almost neutral, with low exchange acidity. Organic matter $(\mathrm{OM})$ and total nitrogen $(\mathrm{N})$ are high, and the $\mathrm{C} / \mathrm{N}$ ratio varies largely, suggesting a high diversity of organic matter sources [30,31].

\section{Characteristics of Mangrove Soils}

Mangrove soils to $60 \mathrm{~cm}$ depth are heavily reduced with redox potential ranging from $-321 \mathrm{mV}$ to $-52 \mathrm{mV}$ [29]. According to [32], sulfate reduction (optimal at $-100 \mathrm{mV}$ ) and methanogenesis (optimal at $-200 \mathrm{mV}$ ) are dominant processes in this condition. The soils are acidic $\left(\mathrm{pH}_{\mathrm{H} 2 \mathrm{O}} 5.63 \pm 0.15, \mathrm{pH}_{\mathrm{KCl}} 5.27 \pm 0.18\right)$ as a result of pyrite oxidation when exposed to the open air (Eq. 1). The presence of pyritic material in the soils was confirmed by the sign of pyrite oxidation (Figure 4) and the high acidity of soils deposited on the dikes (Table 2). Pyrite oxidation forms precipitated $\mathrm{Fe}(\mathrm{OH})_{3}$, which is harmful to shrimps because it adheres to the gills and retards shrimp respiration [33]. The problem is, however, rather mild because the farms are inundated for most of the time during the production cycle.

$$
4 \mathrm{FeS}_{2}+15 \mathrm{O}_{2}+14 \mathrm{H}_{2} \mathrm{O} \rightarrow 4 \mathrm{Fe}(\mathrm{OH})_{3}+8 \mathrm{SO}_{4}^{2-}+16 \mathrm{H}^{+}
$$

Soil organic carbon (SOC) $(5.19 \pm 0.59 \%)$ is high in the top sediment as a result of an abundant supply from mangrove debris but drops sharply from a $80 \mathrm{~cm}$ depth. High exchange acidity is found in mangrove soils rich in SOC $[4,29]$.
Table 1: Basic parameters of channel sediment in the organic shrimp model [29].

\begin{tabular}{|c|c|c|c|}
\hline Parameter & Min & Max & 95\% Confidence interval \\
\hline Redox potential (mV) & -299.00 & -1.00 & $-177.75 \pm 14.75$ \\
\hline $\mathrm{pH}$ of fresh sediment & 6.05 & 7.64 & $7.20 \pm 0.07$ \\
\hline $\mathrm{pH}_{\mathrm{H} 2 \mathrm{O}}$ & 6.63 & 7.78 & $7.20 \pm 0.06$ \\
\hline $\mathrm{pH}_{\mathrm{KCl}}$ & 6.35 & 7.43 & $6.92 \pm 0.07$ \\
\hline Exchange acidity $\left(\mathrm{cmol}_{\mathrm{c}} \mathrm{kg}^{-1}\right)$ & 0.03 & 0.12 & $0.05 \pm 0.00$ \\
\hline $\mathrm{Fe}^{2+} / \mathrm{Fe}^{3+}$ & 0.55 & 93.30 & $9.89 \pm 3.35$ \\
\hline $\mathrm{OM}(\%)$ & 2.41 & 9.30 & $4.20 \pm 0.33$ \\
\hline Total Nitrogen (\%) & 0.18 & 0.51 & $0.30 \pm 0.02$ \\
\hline $\mathrm{C} / \mathrm{N}$ & 3.90 & 12.16 & $8.12 \pm 0.36$ \\
\hline
\end{tabular}

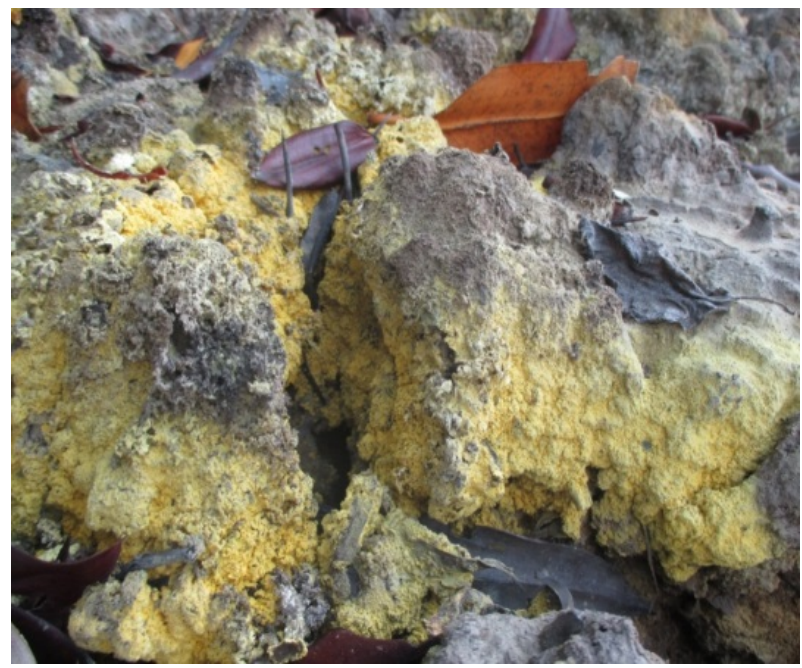

Figure 4: Mangrove soils (with clear signs of pyrite oxidation) on the dikes of the model.

Table 2: Acidity of mangrove soils deposited on the dikes [29].

\begin{tabular}{|l|c|c|c|c|}
\hline Parameter & $\mathbf{p H}_{\mathrm{H} 2 \mathrm{O}}$ & $\mathbf{p H}_{\mathrm{KCl}}$ & Exchange acidity & ${\text { Exchangeable } \mathbf{~ A l}^{3+}}^{\mathbf{3}}$ \\
\hline Range & & & $\mathbf{c m o l}_{\mathbf{c}} \mathbf{k g}^{-1}$ & $\mathbf{c m o l}_{\mathbf{c}} \mathbf{k g}^{-1}$ \\
\hline $95 \%$ Confidence interval & $2.51 \pm 0.72$ & $2.03 \pm 0.21$ & $11.56 \pm 2.69$ & $6.45-7.49$ \\
\hline
\end{tabular}




\section{Shrimp Yields and Relationships with Physico-Chemical Properties}

The total shrimp yield was low (355.4 $\mathrm{kg} \mathrm{ha}^{-1}$ year $\left.^{-1}\right)$. The wild shrimps (Penaeus indicus H. Milne Edwards, 1837, Penaeus merguiensis de Man, 1888 [in de Man, 1887-1888], Metapenaeus ensis (De Haan, 1844 [in De Haan, 1833-1850]) and Metapenaeus lysianassa (de Man, 1888 [in de Man, 1887-1888])) contributed 55\% to the total shrimp yield [11]. Shrimp yield of this model is similar or even somewhat higher compared to those in integrated shrimpmangrove systems in the Mekong deta of Vietnam [15,17,34,35] and Indonesia [36]. The model is, however, no longer as productive as it was in a recent past (550-600 $\mathrm{kg} \mathrm{ha}^{-1}$ year $\left.^{-1}\right)$ [16]. As there was no marked difference in stocking densities between now and the past, the most probable reason for this could be a decline in water and sediment quality of the model.

There are positive correlations ( $\mathrm{p}<0.05)$ between total shrimp yield/ wild shrimp yield and water depths [11], in agreement with previous findings in similar systems in the Mekong delta where the water depths ranged between $50-80 \mathrm{~cm}[15,37]$. The finding suggests that the model should be made deeper, such as to a depth of about $80-90 \mathrm{~cm} \mathrm{[4].}$ Positive correlations between total shrimp yield with $\mathrm{pH}_{\mathrm{H} 2 \mathrm{O}}(\mathrm{p}<0.05)$ and $\mathrm{pH}_{\mathrm{KCl}}(\mathrm{p}<0.001)$ suggest that shrimps grow well in neutral or nearneutral pond bottom [11], similar to previous findings in aquaculture ponds $[38,39]$. Turbidity is positively correlated with wild shrimp yield [11], most probably due to the positive relationship between turbidity and organic matter content in pond water [40,41]. Inverse relationships between total shrimp yield/black tiger shrimp yield and $\mathrm{Fe}^{2+}$ [11] confirm the negative impacts of iron to shrimp growth as shown in previous research [33,42]. [5] found that forest ratios have a direct impact on the total shrimp yield, and that these ratios should be $50 \%$, well in accordance with the guidelines for this model [16]. In the same model in Rach Goc commune, Ngoc Hien district, Camau province, farmers claimed that the best mangrove coverage on their farms should lie between $30-50 \%$ for the highest productivity [43].

\section{Income from the Model}

Shrimps provide short-term income while mangroves provide the long-term for the local shrimp farmers. Currently, data of benefits from shrimps is not available. Regarding the forest, farmers are allowed to exploit the mature mangroves ( $\geq 10$ years old) by trimming (up to $\leq 50 \%$ forest area) or complete logging followed by reforestation. Farmers would receive all benefits from the mangroves if they invest and take care of the forests by themselves. In case farmers rent the land and receive supports (capital, techniques, etc.) from the Board of forest management for reforestation, they are to receive $30 \%$ benefits from the mangroves. According to the local shrimp farmers in Camau province, it was worth about 50,000 USD ha-1 of mangrove forest in the model (10,000 mature trees on average) in 2016 [4].

\section{Can this Organic Shrimp Model be Expanded Further in the Mekong Delta of Vietnam?}

Organic agriculture in Vietnam is still at an early stage and has not developed rapidly $[44,45]$. However, the Vietnamese government has issued new policies to encourage organic agriculture development in the Mekong Delta and the whole country [46-48]. Given the favorable physical and socio-economic conditions and as supported by FAO, the government has planned to expand organic certification to integrated shrimp-mangrove farming systems along the coast of the Mekong delta of Vietnam [19,49].

The physical conditions of the organic shrimp model are in general appropriate to shrimp growth, although several drawbacks (e.g. iron content and turbidity in the water, precipitated $\mathrm{Fe}(\mathrm{OH})_{3}$ from pyrite oxidation, water depth, and forest ratios) might affect shrimp yields $[5,11,29]$. While the model seems appropriate in physical terms, several managerial challenges still exist. For examples, according to the local shrimp farmers, there are still illogicalities in the regulations for the forest ratios (calculated for each household, not a group of households using the same water sources), total farm areas (not accepting farms of less than $3 \mathrm{ha}$ ), assessment methods for certification of the IMO, inappropriate mechanism of payment, benefit sharing, and the sharing of mangrove products (e.g. wood and other forest products) between shrimp farmers and the Board of forest management $[4,20]$. Accordingly, this model has been not very interesting to the local communities [4]. In Ngoc Hien district (Camau province), certified farms of this model do not show significant differences to non-certified farms in terms of social and environmental benefits [43]. The author suggests that rather than being a tool for improvement, 'Naturland' certification for integrated shrimp-mangrove systems in Camau province has become an end in itself. Although being strongly supported by the government, this model would be largely expanded in the coastal part in the Mekong delta of Vietnam if these issues are properly solved.

\section{References}

1. Willer H, Lernoud J (2019) The World of Organic Agriculture - Statistics and Emerging Trends 2019. Research Institute of Organic Agriculture (FiBL), Frick, and IFOAM - Organics International, Bonn, Germany.

2. FAO (2021) Family Farming Knowledge Platform - The World of Organic Agriculture 2021

3. Jonell M, Henriksson PJG (2015) Mangrove-shrimp farms in Vietnam-comparing organic and conventional systems using life cycle assessment. Aquaculture 447: 66-75.

4. Tho N (2016) Assessing the natural food basis for shrimps in relation to the hydrogeochemical characteristics of the organic shrimp model in Nam Can district, Camau province -Proposing solutions to improve the model. Vietnam Academy of Science and Technology. Project coded VAST.CTG.06/14-16.

5. Thai TT, Tho N, Yen NTM, Quang NX, Thao NTP, et al. (2021) Effect of Mangrove Cover on Shrimp Yield in Integrated Mangrove-Shrimp Farming. Asian Fisheries Science 34: 269-277.

6. Willer H, Lernoud J, Kilcher L (2014) The world of organic agriculture - Statistics and emerging trends 2014: Frick. Switzerland: Research Institute of Organic Agriculture (FiBL) \& Bonn: International Federation of Organic Agriculture Movements (IFOAM).

7. iPFES (2015) Study report - Economic valuation of ecosystem services to develop payment for forest environmental service mechanism on aquaculture in Lao Cai, Thua Thien Hue and Ca Mau provinces. Vietnam Forest Protection and Development Fund (Vnff), Vietnam 188

8. Ahmed N, Thompson S, Glaser M (2018) Integrated mangrove-shrimp cultivation: Potential for blue carbon sequestration. Ambio 47: 441-452. [crossref]

9. Naturland (2019) Naturland standards organic aquaculture.

10. Mukul AZA, Afrin S, Hassan MM (2013) Factors affecting consumers' perceptions about organic food and their prevalence in Bangladeshi organic preference. Journal of Business and Management Sciences 1: 112-118. 
11. Tho N, Tu TTK, Chi NTH (2019) Shrimp yield in relation to the ecological parameters of an organic shrimp model in the Mekong delta of Vietnam: A case study. Asian Fisheries Science 32: 154-161.

12. Naturland (2008) Naturland Standards for Organic Aquaculture

13. McEwin A, McNally R (2014) Organic Shrimp Certification and Carbon Financing: An Assessment for the Mangroves and Markets Project in Ca Mau Province, Vietnam. International Climate Initiative (IKI), SNV Smart Development Works.

14. Brennan D, Clayton H, Be TT (2000) Economic characteristics of extensive shrimp farms in the Mekong delta. Aquaculture Economics \& Management 4: 127-139.

15. Johnston D, Trong NV, Tien DV, Xuan TT (2000) Shrimp yields and harvest characteristics of mixed shrimp-mangrove forestry farms in southern Vietnam: factors affecting production. Aquaculture 188: 263-284

16. Camimex (2012) Internal control system, Camimex - Ngoc Hien organic project.

17. Ha TTT, van Dijk H, Bush SR (2012a) Mangrove conservation or shrimp farmer's livelihood? The devolution of forest management and benefit sharing in the Mekong Delta, Vietnam. Ocean \& Coastal Management 69: 185-193.

18. Omoto R (2012) Small-scale producers and the governance of certified organic seafood production in Vietnam's Mekong Delta. PhD Thesis, University of Waterloo.

19. Ha TTT, Bush SR, Mol APJ, van Dijk H (2012b) Organic Coasts? Regulatory Challenges of Certifying Integrated Shrimp-Mangrove Production Systems in Vietnam. Journal of Rural Studies 28: 631-639.

20. Ha TTT (2015) Naturland organic shrimp certification in protecting mangrove forests in Camau - Prospects and challenges. Journal of Science and Forestry Technology 3: 101-109.

21. FAO (2007) Improving Penaeus monodon hatchery practices - Manual based on experience in India. FAO Fisheries Technical Paper 446.

22. Tho N, Khanh DNN (2018) Assessing the hydrochemical characteristics of the organic shrimp model at Tam Giang commune, Nam Can district, Ca Mau province. Journal of Marine Science and Technology, Vietnam Academy of Science and Technology 18: 205-213.

23. Loc NX, Nga TT, Tinh HQ (2008) Water quality in extensive shrimp ponds (Penaeus monodon) in Tam Giang I forestry-fisheries enterprises, Ngoc Hien district, Camau province. Science Journal of Can Tho University 99: 202-209.

24. Toan LB (2011) Studying the mixed mangrove-shrimp systems in Ngoc Hien district, Camau province. PhD Thesis, Ho Chi Minh City University of Agriculture and Forestry 144.

25. Minh LQ, Tuong TP, van Mensvoort MEF, Bouma J (1997) Tillage and water management for riceland productivity in acid sulfate soils of the Mekong delta, Vietnam. Soil and Tillage Research 42: 1-14.

26. Tuong TP, Minh LQ, Ni DV, van Mensvoort MEF (1998) Reducing acid pollution from reclaimed acid sulphate soils: experiences from the Mekong delta, Vietnam. In: LS. Pereira, JW Gowing (1998) Water and the Environment: Innovation Issues in Irrigation and Drainage. E. and FN. Spon, London 75-83.

27. Phong ND, Tuong TP, Phu ND, Nang ND, Hoanh CT (2013) Quantifying Source and Dynamics of Acidic Pollution in a Coastal Acid Sulphate Soil Area. Water, Air, \& Soil Pollution 224: 1765

28. Haws MC, Boyd CE (2001) Methods for improving shrimp farming in Central America. Central American University Press-UCA, 292.

29. Tho N, Khanh DNN, Tu TTK (2017) Risk of acidification of the organic shrimp model at Tam Giang commune, Nam Can district, Ca Mau province. Science \& Technology Development 20
30. Meyers PA (1997) Organic geochemical proxies of paleoceanographic, paleolimnologic, and paleoclimatic processes. Org Geochem 27: 213-250.

31. Lamb AL, Wilson GP, Leng MJ (2006) A review of coastal palaeoclimate and relative sea-level reconstructions using $\mathrm{d} 13 \mathrm{C}$ and $\mathrm{C} / \mathrm{N}$ ratios in organic material. Earth $\mathrm{Sci}$ Rev 75: 29-57.

32. Avnimelech Y, Ritvo G (2003) Shrimp and fish pond soils: processes and management. Aquaculture 220: 549-567.

33. Boyd CE (2008) Iron Important To Pond Water, Bottom Quality. Global Aquaculture Advocate 59-60.

34. Binh CT, Phillips MJ, Demaine H (1997) Integrated shrimp-mangrove farming systems in the Mekong delta of Vietnam. Aquaculture Research 28: 599-610.

35. Bosma RH, Nguyen TH, Siahainenia AJ, Tran HT, Tran HN (2014) Shrimp-based livelihoods in mangrove silvo-aquaculture farming systems. Reviews in Aquaculture 8: 43-60.

36. Fitzgerald WJ (2000) Integrated mangrove forest and aquaculture systems in Indonesia. In Proceedings of the workshop on mangrove-friendly aquaculture. (eds. Primavera JH., Garcia LMB., Castaños MT., Surtida MB.) 21-34. Iloilo City, Philippines.

37. Minh TH, Yakupitiyage A, Macintosh DJ (2001) Management of the integrated mangrove-aquaculture farming systems in the Mekong Delta of Vietnam. Food and Agriculture Organization of the United Nations 24.

38. Banerjea SM (1967) Water quality and soil conditions of fish ponds in some states of India in relation to fish production. Indian Journal of Fisheries 14: 114-115.

39. Boyd CE (1995) Bottom soils, sediment and pond aquaculture. Chapman and Hall, New York 348

40. Azim ME, Verdegem MC, van Dam AA, Beveridge MC (2005) Periphyton: ecology, exploitation and management. CABI Publishing, New York 325.

41. Shaari AL, Surif M, Latiff FA, Omar WM, Ahmad MN (2011) Monitoring of water quality and microalgae species composition of Penaeus monodon ponds in Pulau Pinang, Malaysia. Tropical Life Sciences Research 22: 51-69. [crossref]

42. Poernomo A (1990) Technical constraints in shrimp culture and how to overcome them. In Proceedings of the shrimp culture industry workshop. (ed. Yap, W.G.) 59-66. FAO Fisheries and Aquaculture Department, Jepara City, Indonesia.

43. Baumgartner U, Nguyen TH (2017) Organic certification for shrimp value chains in Ca Mau, Vietnam: a means for improvement or an end in itself? Environ Dev Sustain 19: 987-1002.

44. British Council (2016) Vietnam Social Enterprise Casebook.

45. Presilla M (2018) The development of organic farming in Vietnam. Jurnal Kajian Wilayah 9: 20-32.

46. Toan PV, Minh ND, Thong DV (2019) Organic Fertilizer Production and Application in Vietnam. In: Larramendy M and Soloneski S. (eds): Organic Fertilizers - History, Production and Applications.

47. Nguyen CT, Van TTT (2021) Development of Organic Agriculture in the Mekong Delta - Opportunities and Challenges. European Journal of Development Studies 1: 29-35.

48. GIZ (2021) The potential of digital tools to promote sustainable production in the shrimp aquaculture sector: A case study of the Mekong Delta, Viet Nam. Mekong Delta Climate Resilience Programme (MCRP). Hanoi, October 2021.

49. FAO (2015) Sustainable Shrimp farming project.

\section{Citation:}

Nguyen T, Thi Kim TT (2021) An Overview of the First Organic Shrimp Model in the Mekong Delta of Vietnam. Aquac Fish Stud Volume 3(4): 1-5. 